\title{
The Cretaceous tectonic event in the Qiangtang Basin and its implications for hydrocarbon accumulation
}

\author{
Li Yalin ${ }^{1 *}$, Wang Chengshan ${ }^{1}$, Li Yongtie ${ }^{2}$, Ma Chao ${ }^{1}$, Wang Licheng ${ }^{1}$ and \\ Peng Shaonan ${ }^{1}$ \\ ${ }^{1}$ State Key Laboratory of Geological Processes and Mineral Resources, Research Center for Tibetan Plateau Geology, China \\ University of Geosciences, Beijing 100083, China \\ ${ }^{2}$ Petroleum Exploration and Development Research Institute, PetroChina, Beijing 100083, China
}

(C) China University of Petroleum (Beijing) and Springer-Verlag Berlin Heidelberg 2010

\begin{abstract}
The tectonic event during Cretaceous and its relationship with hydrocarbon accumulation in the Qiangtang Basin is discussed based on zircon $\mathrm{U}-\mathrm{Pb}$ dating and the study of deformation, thermochronology and hydrocarbon formation. LA-ICPMS zircon U-Pb dating indicates that the tectonic event took place during the Early-Late Cretaceous (125-75Ma). The event not only established the framework and the styles of structural traps in the basin, but also led to the cessation of the first hydrocarbon formation and the destruction of previous oil pools. The light crude oil in the basin was formed during the second hydrocarbon formation stage in the Cenozoic, and ancient structural traps formed during the Cretaceous event are promising targets for oil and gas exploration.
\end{abstract}

Key words: Qinghai-Tibet plateau, Qiangtang Basin, tectonic event, Cretaceous, hydrocarbon accumulation

\section{Introduction}

The Qiangtang Basin, with a total area of $180,000 \mathrm{~km}^{2}$, is the largest and potentially the most oil-gas-bearing basin in the Qinghai-Tibet plateau (Zhao et al, 2001; Wang and Yi, 2001; Wang et al, 2006; 2005). The Mesozoic marine deposits are the target for oil and gas exploration. However, the basin has undergone multi-stage and complicated tectonic events since the Cretaceous and became a typical superimposed basin. The hydrocarbon accumulation and preservation conditions have been the key problem for oil and gas evaluation (Wang et al, 2006). The angular unconformity between the Upper Cretaceous Abushan Formation and the underlying Jurassic-Lower Cretaceous strata is a sign of the first tectonic event that the prototype basin has undergone. It has been recognized that this tectonic event had an influence on the hydrocarbon accumulation in the Qiangtang Basin (Zhao et al, 2001; Wang et al, 2005; Qin, 2006; Li et al, 2008). However, the characteristics and the age of the tectonic event are still at issue because of the lack of accurate geochronology research on the event. It restricts the understanding of the relationship between the event and hydrocarbon accumulation in the Qiangtang Basin.

Based on the new investigations in recent years,

*Corresponding author. email: liyalin@cugb.edu.cn

Received November 5, 2009 we studied the age, deformation characteristics and thermochronology of the tectonic event, and discuss its relationship with hydrocarbon accumulation and preservation in this paper.

\section{Geological backgrounds}

The Qiangtang Basin lies between the Jinshajiang and Bangonghu-Nujiang suture zones with average elevation of more than 4,500 m (Fig. 1), and has undergone foreland basin evolution during the Late Triassic (Wang and Yi, 2001) and passive ocean margin basin evolution during the Jurassic (Wang et al, 2005). Deposits more than 5,000-6,000 m thick were formed during the Mesozoic.

These marine deposits are the main targets for oil and gas exploration. The source rocks are widely developed in the Qiangtang Basin, and consist mostly of the Upper Triassic Xiaochaka Formation, Middle Jurassic Buqu Formation and Xiali Formation, as well as the Upper Jurassic Suowa Formation (Wu et al, 2008; Qin, 2006; Zhao et al, 2001; Wang and Yi, 2001; Wang et al, 2005). The source rocks include mudstones and carbonate rocks, which form several effective hydrocarbon plays. Previous research indicates that the Qiangtang Basin has good oil-gas potential, with the total resources of (40.3-86.3) $\times 10^{8} \mathrm{t}$ (Wang and Yi, 2001; Wang et al, 2005; Liu et al, 2007).

The Qiangtang Basin has been in the marine prototype 


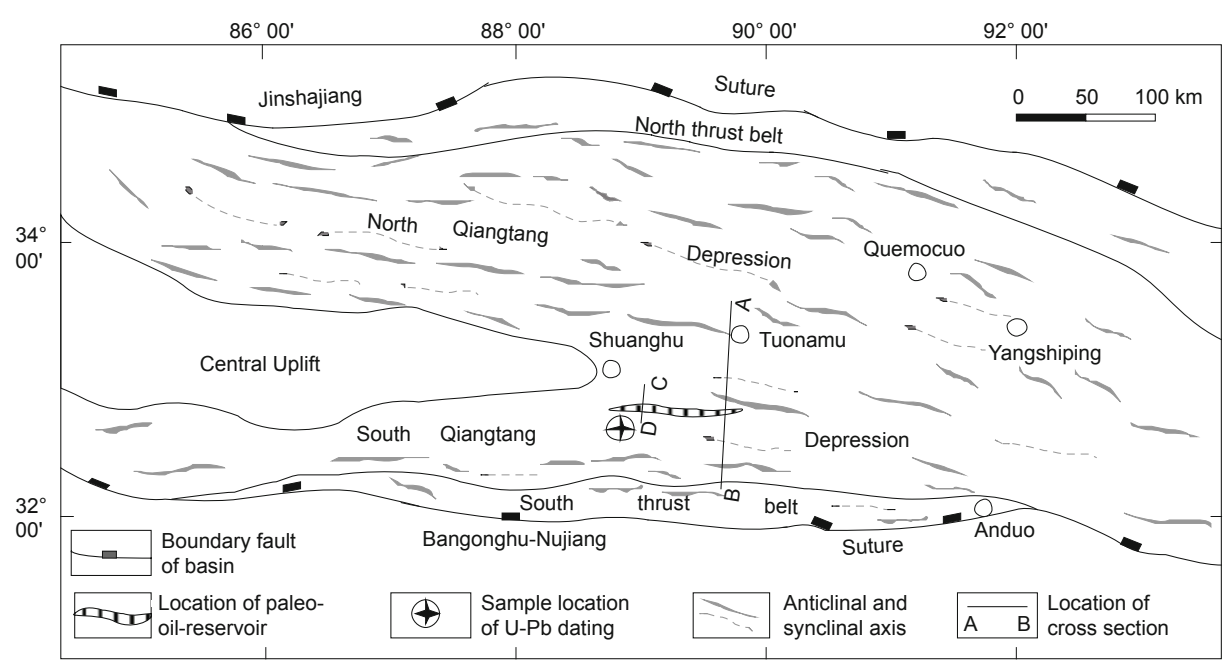

Fig. 1 Sketch map showing the tectonic units and fold distribution in the Qiangtang Basin

basin stage since the Late Cretaceous. Due to the orogeny and uplifting of the plateau, the basin has undergone multistage reformation and has a complicated tectonic framework and varying structural styles. The discovery of the Longeni palaeo-oil-reservoir belt in the south of the Qiangtang Basin further verifies that the Qiangtang Basin has experienced large scale hydrocarbon accumulation and complicated reconstruction (Wang et al, 2004).

The tectonic event discussed in this paper is that marked by the angular unconformity between nonmarine Abushan Formation and the underlying Jurassic-Early Cretaceous marine strata. The terrestrial clastic rocks of the Abushan Formation lie over different layers of Jurassic-Early Cretaceous marine strata, and the angular unconformity is considered as the result of Qiangtang-Lhasa collision (Zhao et al, 2001; Wang et al, 2005; Li et al, 2008).

\section{Age of the tectonic event}

The unconformity plane and the age of underlying strata were studied clearly in the past. However, the age of the Abushan Formation is still disputed, for two main reasons. One is that the Abushan Formation mainly consists of clastic rocks, with a poor fossil record and especially a lack of index fossils. The other reason is that it lacks volcanic rocks that could provide an isotopic age. Suggested ages of the Abushan Formation include the Early Cretaceous (Zhao et al, 2001; Bureau of Geology and Mineral Resources of Xizang, 1993), Late Cretaceous (Wang et al, 2001; Wu, 1986) and Tertiary. This uncertainty has restricted the understanding of the age of tectonic event and the relationship with hydrocarbon accumulation.

In recent years, trachyandesite layers have been discovered at the bottom of the Abushan Formation, south of the Shuanghu area (locus GPS reading 89 $10^{\prime} 15.7^{\prime \prime} \mathrm{E}$, $31^{\circ} 31^{\prime} 22.5^{\prime \prime} \mathrm{N}$ ) (Fig. 1). Zircons from the trachyandesite have been dated by the LA-ICP-MS method at the State Key Laboratory for Mineral Deposits Research in Nanjing University, utilizing an Agilent 7500a ICP-MS coupled with a UP213 laser-ablation system made by New Wave. A spot size of $30 \mu \mathrm{m}$ with a repetition rate of $5 \mathrm{~Hz}$ was applied to all analyses. The analytical procedures for the U-Pb dating are described in detail by Belousova et al (2001) and Jackson et al (2004). Cathodoluminescence (CL) images reveal that the zircon crystals possess clear oscillatory compositional zoning and lack inherited cores, suggesting zircons were crystallized from magmatic melts (Fig. 2). Chronology results from zircon samples (L-6-01) analyzed by LA-ICP-MS indicated that ${ }^{206} \mathrm{~Pb} /{ }^{238} \mathrm{U}$ ages of all the 20 analyses are $(74 \pm 1)-(78 \pm 2) \mathrm{Ma}$ and the weighted average age is $75.9 \pm 0.5 \mathrm{Ma}(\mathrm{MSWD}=1.08$, $n=20$ ) (Fig. 2). The ages of 20 zircon samples obtained by LA-ICP-MS agree well within error. This indicates that the lavas of the Abushan Formation occurred in the Late Cretaceous Companian period.

In addition, the Xueshan Formation is thought to be formed at the Kimmeridgian-Tithonian stage of the Late Jurassic, its latest marine strata reached into the BerriasianBarremian (145-125 Ma) of the Early Cretaceous according to paleontology research (Tan et al, 2004; Fang et al, 2002; $\mathrm{Li}$ and Batten, 2004). The ages of the Xueshan Formation and Abushan Formation illustrate that the tectonic event took place during the Early to Late Cretaceous (125-75 Ma). Our conclusion of the age of the tectonic event is consistent with the results obtained from the Bangonghu-Nujiang suture by Kapp et al (2007).

\section{Tectonic event and hydrocarbon accumulation}

\subsection{Tectonic event and hydrocarbon formation}

The burial depth and geotemperature are key factors for hydrocarbon formation. These are controlled by the uplifting and denudation caused by the tectonic event. In order to understand the effect of the Cretaceous tectonic event on hydrocarbon formation, we reconstructed the subsidenceevolutionary history of the south and north Qiangtang Basin based on the thermal evolution of source rocks, ancient 

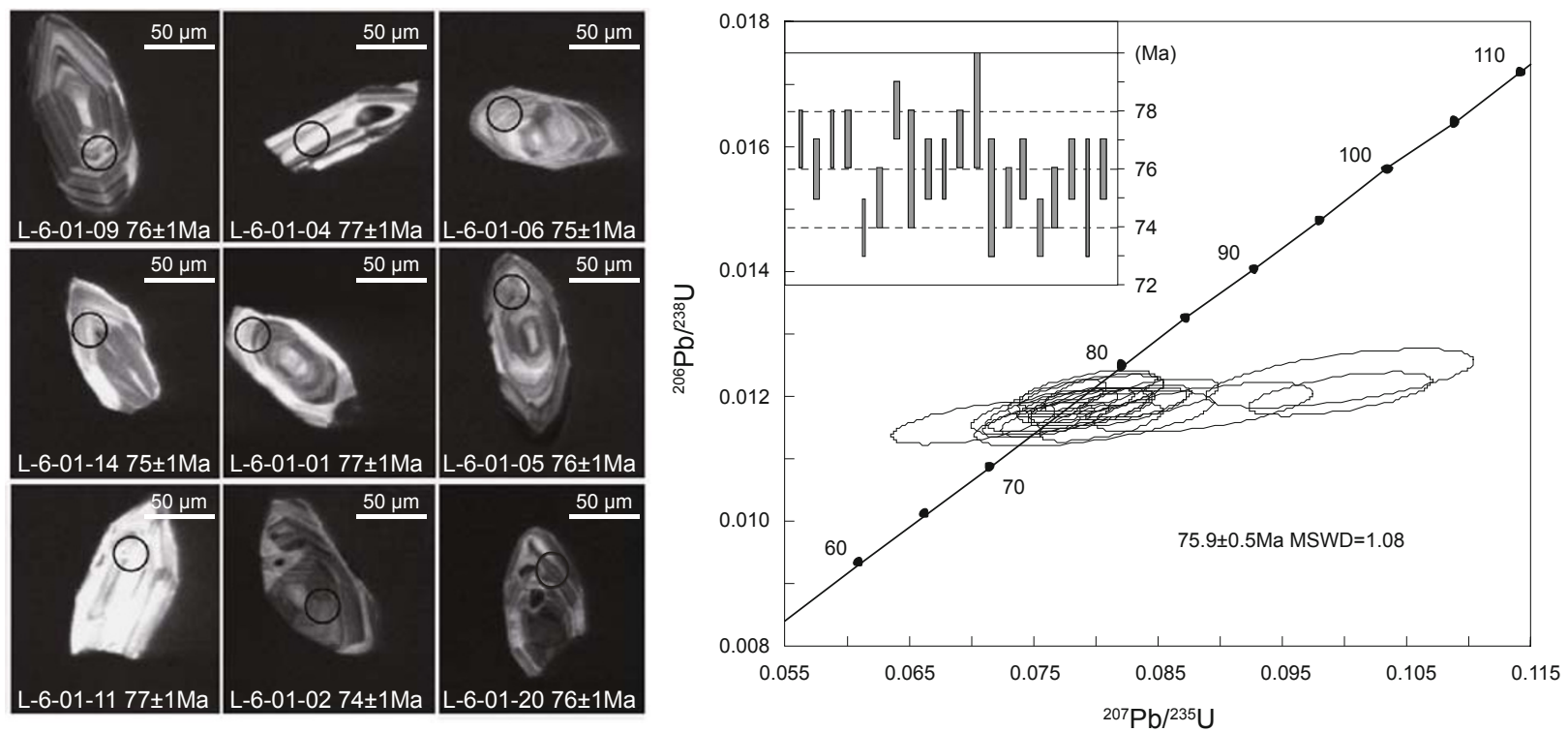

Fig. $2 \mathrm{CL}$ photos and U-Pb concordia diagrams of zircons from volcanic rocks of the Abushan Formation

geothermal gradient, depth of stratum and tectonic evolution (Fig. 3).

The results showed that both the north and the south Qiangtang Basin had two stages of hydrocarbon formation. The first stage occurred in the Late Jurassic-Early Cretaceous, namely, after the Jurassic marine sedimentation of the Xueshan Formation $\left(\mathrm{J}_{3} \mathrm{x}\right)$ and before the Cretaceous tectonic event. The Jurassic source rocks were buried under 2,500$5,000 \mathrm{~m}$ and 2,500-3,500 $\mathrm{m}$ in the south and north of the basin respectively. The first hydrocarbon formation was the middle Jurassic Buqu Formation $\left(\mathrm{J}_{2} \mathrm{~b}\right)$ and Xiali Formation $\left(\mathrm{J}_{2} \mathrm{x}\right)$ generating immature-low mature oil, while the Suowa Formation $\left(\mathrm{J}_{3} \mathrm{~s}\right)$ had just entered the threshold, the main part of it was at the immature stage. During the late Early Cretaceous to Palaeogene, most of the Qiangtang Basin had not yet reached the maximum burial depth of Late Jurassic and the formation of oil and gas ceased.

The second hydrocarbon formation of Jurassic source rocks occurred in Miocene-Pliocene (Fig. 3), the source rocks were buried at the depth of $4,000 \mathrm{~m}$ in the basin by widespread development of Tertiary sedimentation. During this period, the Jurassic source rocks generated a large amount of light oil in the late mature stage. It is also the hydrocarbon migration period (Wang et al, 2004).

The history of hydrocarbon formation in the Qiangtang Basin indicated that the Cretaceous tectonic event significantly controlled hydrocarbon accumulation. In the late Jurassic-Early Cretaceous, oil and gas was initially generated from the main source rocks that had reached the maximum burial depth or paleotemperature. During the tectonic event (125-75 Ma), the uplifting and denudation led to the burial depth of the source rocks being decreased and hence the cessation of hydrocarbon formation. In the Late Cretaceous, with the development of the Abushan Formation, the Jurassic source rocks were buried under 2,500-3,000 m and lowmature oil was generated (Fig. 3(b)). The basin was uplifted and eroded again because of the India-Eurasia collision and uplifting of the plateau in early Paleogene, and this stage was sustained until the second hydrocarbon formation during Miocene - Pliocene.
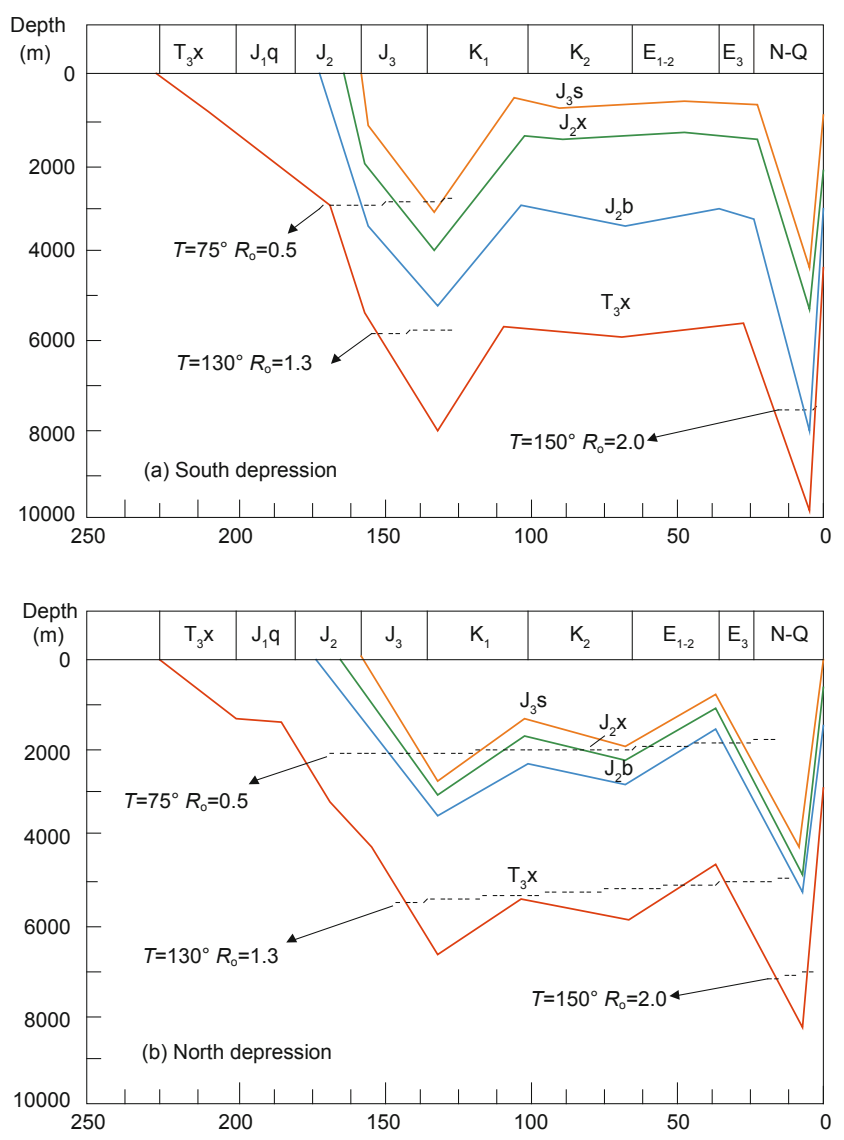

Fig. 3 Subsidence-evolution history curves of the source rocks in the Qiangtang Basin

\subsection{Tectonic event and formation of structural traps}

The tectonic event is the key stage of structural trap development, and the contemporaneous formation of 
structural traps with the hydrocarbon formation can be regarded as important for oil and gas accumulation. Anticline traps are widely developed in the Qiangtang Basin and mainly consist of Jurassic strata. The axes of these anticline traps are EW and NW and have zonal distribution (Fig. 1). The scale and shape of these traps are different in the basin. In the edges and the central uplift of the basin, the anticline traps are smaller and tighter with extended lengths of 20-30 $\mathrm{km}$, while they are larger and broader in the south and north with extended lengths of 50-100 km, and the anticlines are broader in the north than in the south. These anticlines are main structural traps of the basin.

However, the ages of anticlines and their relationship with the hydrocarbon formation processes is ill-defined, because the basin has undergone multi-stage deformation since the Cretaceous. Due to this multi-stage deformation of the Qiangtang Basin, the balanced cross section technique was employed to analyze the deformation during the Cretaceous tectonic event. The Tuonamu-Angdaercuo section was chosen for reconstructing the balanced section (Fig. 1). The reasons are: 1 ) we have conducted 1:100,000 geological survey along this route; 2) the section is orthogonal to the strikes and axes of faults and folds; 3 ) the outcrops are good, and marker beds are easily recognized in the field; 4) the geological section is parallel to the 97990 seismic profile, and the deep structure can be well described.

The Tuonamu-Angdaercuo section lies in the centre of the Qiangtang Basin, and spans the greater part of the northern and southern depressions (Fig. 1). This section mainly consists of Jurassic and Triassic strata. The boundary between the middle Jurassic Buqu Formation and the Xiali Formation is used as the marker bed for estimating the shortening of the
Jurassic strata (Fig. 4). This is because the Buqu and Xiali Formations are characterized by carbonate rocks and clastic rocks respectively, the boundary of which is widely exposed in geological section and is easily identified in the seismic section. The reconstructed balanced cross sections are shown in Fig. 4. The crustal shortening ratio is calculated for the study area with line length balanced technique. The formula is $R=\left(1-L / L_{0}\right) \times 100 \%$ ( $R$ : shortening ratio; $L$ : present length; $L_{0}$ : original length).

The balanced section shows that the length of the Jurassic strata in the region is $142 \mathrm{~km}$ now, while the original length was $233.5 \mathrm{~km}$, indicating that the shortening is $91.5 \mathrm{~km}$ and the shortening ratio is $39.2 \%$. Considering the cross section is located in the central part and belongs to the weak deformation area of the basin, our result of the Jurassic shortening ratio is consistent with the conclusion drawn by Huang and Li (2007), which is 40\%-50\%. However, our study show that the shortening ratio of the Tertiary strata in the Qiangtang Basin is 15\%-19\% ( $\mathrm{Li}$ et al, 2000), indicating that the basin was intensively shortened during Mesozoic. In addition, we have estimated the shortening ratio of Jurassic and Cretaceous tectonic layers by analyzing the fold style in Cretaceous (13 folds) and Jurassic strata (206 folds). The results reveal that the Jurassic strata have been shortened $7.7 \%$ since Cretaceous, while the total shortening ratio is $23.3 \%$ (Li et al, 2008) caused by folding. The above results indicate that the basic tectonic framework and the anticlines of the Jurassic tectonic layers were formed during the period of the Cretaceous tectonic event. This tectonic event was the result of the Qiangtang-Lhasa collision that made the anticlines in the south tighter than those in the north. Moreover, the Miocene strata are horizontal, indicating that there has been

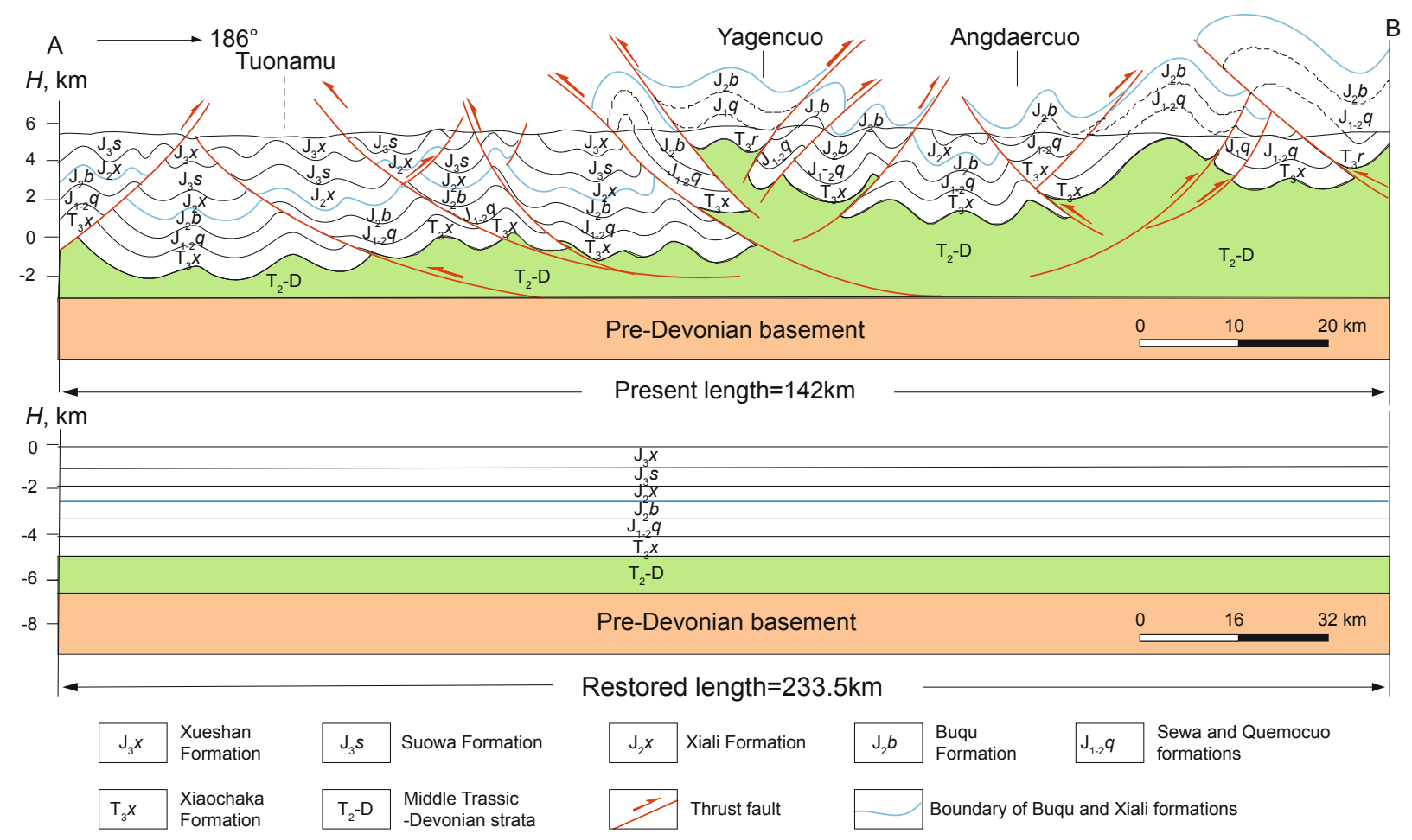

Fig. 4 Balanced cross section of the Tuonamu-Angdaercuo area in the Qiangtang Basin 
no folding since Miocene. The anticlines formed during the Cretaceous event are effective traps for the second period of hydrocarbon formation in the Cenozoic.

\subsection{Tectonic event and oil-gas preservation}

The tectonic movement and uplifting would have reconstructed and destroyed pre-formed hydrocarbon pools, causing the redistribution of oil and gas. The Cretaceous tectonic event resulting in tectonic shortening would also lead to the uplifting and denudation of the basin, which has been verified in the Cuoqin Basin, south of the BangonghuNujiang suture zone (Murphy et al, 1997; Kapp et al, 2005). The Qiangtang Basin with a current average elevation of $4,500 \mathrm{~m}$ is the result of multiple late tectonic events (Wang et al, 2006). To explore the uplifting and denudation caused by the Cretaceous tectonic event, we studied the tectono-thermal geochronology in the Tuonamu, Yanshiping and Longeni areas (Fig. 1).

Apatite fission track analysis of five samples from the Xueshan Formation in the Tuonamu area of northern Qiangtang depression shows that all the samples are between (116.5 \pm 7.0$) \mathrm{Ma}$ and $(83.8 \pm 10.0)$ Ma except for one with the age of $(64.8 \pm 7.4) \mathrm{Ma}$. The ages of two samples from the Abushan Formation are (151.7 \pm 11.9$) \mathrm{Ma}$ and $(128.4 \pm 11.8)$ Ma, which are older than the stratigraphic age, indicating that they were in the partial annealing zone, thus they represent the cooling age of source rocks. The ages of two samples from the Quemocuo and Xiali Formations in the Yanshiping area are $(37.7 \pm 3.0) \mathrm{Ma}$ and $(47.3 \pm 4.0) \mathrm{Ma}$. The analysis of four samples from the Xiali and Quemocuo Formations in the Longeni area of southern Qiangtang depression shows that the ages are between $(83 \pm 6) \mathrm{Ma}$ and $(160 \pm 11) \mathrm{Ma}$, of which

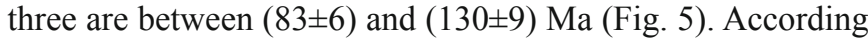
to the research of Liu et al (2009), the ages of twenty samples from the southern Qiangtang depression are between $(10.3 \pm 1.2)$ and $(132 \pm 17.8) \mathrm{Ma}$, which can be divided into two age groups of 78-132 Ma (8 samples) and 40-59 Ma (8 samples). The ages of two Permian samples in central uplift are (69.8 \pm 4.2$) \mathrm{Ma}$ and $(124.9 \pm 12.3)$ Ma while three Triassic samples in southern Qiangtang depression are (25.7 \pm 2.9$) \mathrm{Ma}$, (77.8 \pm 5.5$) \mathrm{Ma}$ and (101.6 \pm 2.2$) \mathrm{Ma}$.

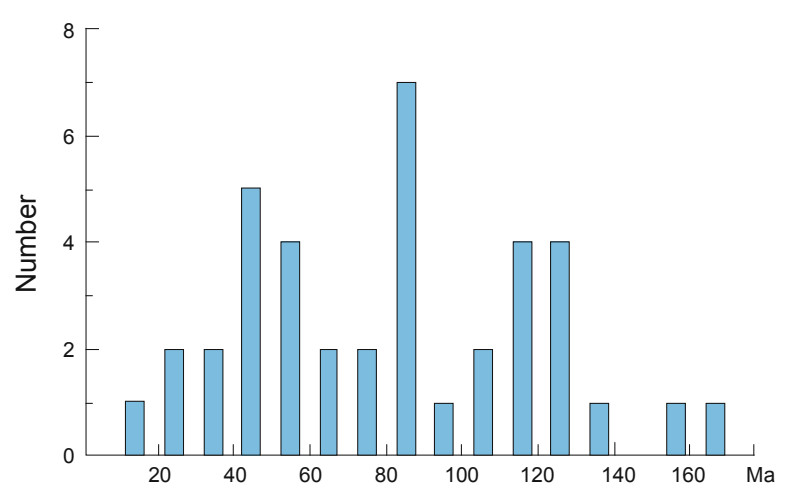

Fig. 5 Distribution histogram of apatite fission track ages

Based on the above statistical analysis of 39 samples, we obtain the conclusion that fission track ages are rarely affected by stratigraphic age or sample location, implying that the Qiangtang Basin has experienced two stages of uplifting and denudation during 80-130 Ma and 40-60 Ma. The second stage was coincident with the age of India-Eurasian collision and Cenozoic uplifting of the plateau (Aitchison et al, 2007; Wang et al, 2008), while the first stage was at the same time with Cretaceous tectonic event and cessation of hydrocarbon formation (Fig. 3), indicating that the Cretaceous tectonic event led to uplifting and denudation of the Qiangtang Basin.

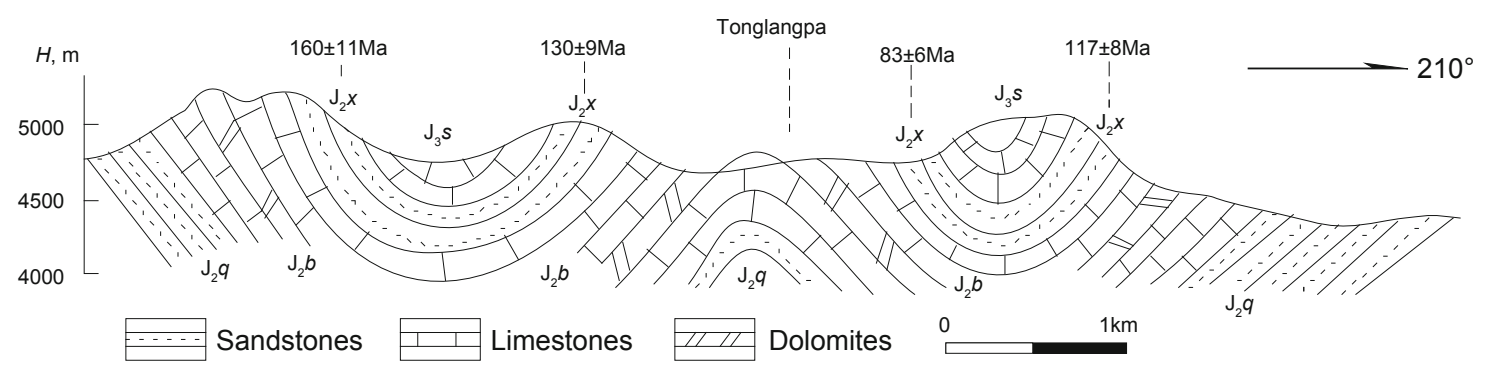

Fig. 6 Cross section of Longeni paleo-oil-reservoir and apatite fission track ages

In addition, our samples in the southern Qiangtang depression are mainly from along the Longeni paleo-oil reservoir cross section, the fission track ages of which are

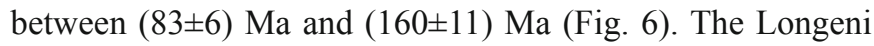
paleo-oil reservoir was formed during 140-150 Ma (Wang et al, 2004), which indicates that the destruction and exposure of the paleo-oil pools are the results of the Cretaceous tectonic event.

\section{Conclusions}

1) The Cretaceous tectonic event took place in the Early
Cretaceous-Late Cretaceous (125-75 Ma). It was a major tectonic movement in the Qiangtang Basin, and influenced the basin evolution and hydrocarbon accumulation.

2) The tectonic event established the basic tectonic framework and pattern of the Qiangtang Basin. The anticlines of Jurassic tectonic layers were mainly formed during this period. These provide the main structural traps of the basin.

3) The Qiangtang Basin has undergone two stages of hydrocarbon formation and accumulation, Cretaceous and Cenozoic. The first stage was contemporaneous with the Cretaceous tectonic event. Due to the uplifting and denudation caused by the Cretaceous tectonic event, the first 
hydrocarbon formation ceased and the early oil pools were destroyed.

4) The main hydrocarbon formation stage was MiocenePliocene. The ancient anticlinal traps formed during the Cretaceous tectonic event provided favorable storage space for the second hydrocarbon accumulation and should be promising targets for future exploration.

\section{Acknowledgements}

This research was supported by the National Natural Science Foundation of China (40672086), the Ministry of Science and Technology "973" Project (2006CB701400) and the Ministry of Land and Resources (XQ2004-06). We thank Dr. Ran Bo and Dr. Wei Yushuai for their assistances in the field. We thank Zhang Yuxiu and anonymous reviewers for critical reviews and suggestions.

\section{References}

Aitchison J C, Ali J R and Davis A M. When and where did India and Asia collide? Journal of Geophysical Research. 2007. 112, B05423: $1-19$

Belousova E A, Griffin W L, Shee S R, et al. Two age populations of zircons from the Timber Creek kimberlites, Northern Territory, as determined by laser-ablation ICP-MS analysis. Australia Journal of Earth Sciences. 2001. 48(5): 757-765

Bureau of Geology and Mineral Resources of Xizang Autonomous Region. Regional Geology of Xizang Autonomous Region. Beijing: Geological Publishing House. 1993. 195-224 (in Chinese)

Fang D Q, Yun J B and Li C. Discussion of the Xueshan Formation in the north of the Qiangtang Basin, Qinghai-Tibet plateau. Journal of Stratigraphy. 2002. 26(1): 68-72 (in Chinese)

Huang J J and Li Y L. Analysis of the finite strain of rocks and shortening of the crust in the Qiangtang Basin. Acta Geologica Sinica. 2007. 81(5): 599-604 (in Chinese)

Jackson S E, Pearson N J, Griffin W L, et al. The application of laser ablation microprobe $\square$ inductively coupled plasma $\square$ mass spectrometry (LAM-ICP-MS) to in situ U-Pb zircon geochronology. Chemical Geology. 2004. 211(1-2): 47-69

Kapp P, DeCelles P G, Gehrels G E, et al. Geological records of the Lhasa-Qiangtang and Indo-Asian collisions in the Nima area of central Tibet. Geological Society of America Bulletin. 2007. 119(78): 917-932

Kapp P, Yin A, Harrison T M, et al. Cretaceous-Tertiary shortening, basin development and volcanism in central Tibet. Geological Society of America Bulletin. 2005. 117(7-8): 865-878

Li J G and Batten D J. Early Cretaceous palynofloras from the Tanggula
Mountains of the northern Qinghai-Xizang (Tibet) Plateau, China. Cretaceous Research. 2004. 25(4): 531-542

Li Y L, Wang C S and Huang J J. Deformation characteristics and finalizing age of the folds in the Qiangtang Basin and their relations to oil and gas accumulation. Oil \& Gas Geology. 2008. 29(3): 283289 (in Chinese)

Li Y L, Wang C S, Wu S, et al. The balanced cross-section and shortening in Qiangtang terrain, Qinghai-Tibet plateau. Earth Science Frontier. 2000. 7(supp.): 188

Liu C Y, Zhao H G, Zhang C, et al. The important turning period of evolution in the Tibet-Himalayan tectonic domain. Earth Science Frontier. 2009. 16(4): 1-12 (in Chinese)

Liu J D, Zhou W, Li Y, et al. Prospective Evaluation of Oil and Gas in Qinghai-Tibet Region. Beijing: Geological Publishing House. 2007. 1-299 (in Chinese)

Murphy M A, Yin A, Harrison T M, et al. Did the Indo-Asian collision alone create the Tibetan Plateau? Geology. 1997. 25(8): 719-722

Qin J Z. Study on organic matter's maturation and hydrocarbon generating history in the Qiangtang Basin. Petroleum Geology \& Experiment. 2006. 28(4): 350-358 (in Chinese)

Tan F W, Wang J, Li Y T, et al. Late Jurassic-Early Cretaceous strata and their sedimentary characteristics in the Qiangtang Basin, northern Tibet. Geology in China. 2004. 31(4): 20-27 (in Chinese)

Wang C S and Yi H S. Geology Evolution and Oil and Gas Prospect Evaluation of Qiangtang Basin in Tibet. Beijing: Geological Publishing House. 2001. 1-215 (in Chinese)

Wang C S, Li Y L and Li Y T. Discussion on evaluation of oil and gas resources in Qinghai-Tibet plateau. Acta Petrolei Sinica. 2006. 27(4): 1-7 (in Chinese)

Wang C S, Yi H S, Liu C Y, et al. Discovery of paleo-oil-reservoirs in the Qiangtang Basin in Tibet and its geological significance. Oil \& Gas Geology. 2004. 25(2): 139-143 (in Chinese)

Wang C S, Zhao X X, Liu Z F, et al. Constraints on the early uplift history of the Tibetan Plateau. PNAS. 2008. 105(13): 4987-4992

Wang J, Tan F W, Li Y L, et al. The Potential of the Oil and Gas Resources in the Major Sedimentary Basin on the Qinghai-Xizang (Tibet) Plateau. Beijing: Geological Publishing House. 2005. 1-317 (in Chinese)

Wu R Z. The stratigraphical system of Qiangtang district in Northern Xizang (Tibet). In: Contribution to the Geology of the QianghaiXizang (Tibet) Plateau (9). Beijing: Geological Publishing House. 1986. 1-32 (in Chinese)

Wu X H, Zhang L, Wang C S, et al. Characteristics of the Mesozoic marine source rocks in the Qiangtang Basin, Tibet. Oil \& Gas Geology. 2008. 29(3): 348-354 (in Chinese)

Zhao Z Z, Li Y T, Ye H F, et al. Petroleum Geology in the Qiangtang Basin. Beijing: Science Press. 2001. 1-398 (in Chinese)

(Edited by Hao Jie) 